\title{
Improving The Quality of Life of Patients with Diabetes Mellitus Type 2 with Treatment Adherence
}

\author{
Yuli Wahyuni'1,2 \\ 1 Klinik Kesehatan Universitas Padjadjaran \\ 2 Fakultas Keperawatan Universitas Padjadjaran
}

\begin{tabular}{|c|c|}
\hline Article Info & Abstract \\
\hline $\begin{array}{l}\text { Article History: } \\
\text { Submitted: May } 31^{\text {st }}, 2021 \\
\text { Accepted: July } 23^{\text {th }}, 2021 \\
\text { Published: August } 31^{\text {st }}, 2021 \\
\text { Keywords: } \\
\text { Diabetes Mellitus type 2; } \\
\text { Quality of life; treatment } \\
\text { adherence }\end{array}$ & $\begin{array}{l}\text { Diabetes is a complex, chronic illness requiring continuous medical care } \\
\text { with multifactorial risk reduction strategy beyond glycemic control. Quality } \\
\text { of life in type } 2 \text { diabetes mellitus (DM) is one indicator of successful disease } \\
\text { management. The aim of this study was to determine the extent to which } \\
\text { medication adherence affects quality of life. The method used by searching } \\
\text { the literature of scientific publications in the time of years between } 2016- \\
2021 \text { using the Pubmed database, Science Direct, Cinahl, Willey Online } \\
\text { Library and google scholar, there were } 2.281 \text { articles. The result of the } \\
\text { literature review found nine articles that fit inclusion and exclusion criteria, } \\
\text { it was found that there are several variables that can improve the quality of } \\
\text { life in type } 2 \text { DM, one of which is treatment adherence. Treatment adherence } \\
\text { is a major predictor in improving the quality of life in type } 2 \text { DM, when } \\
\text { compared with other variables. It is important to develop DM management } \\
\text { interventions that focus on improving treatment adherence. }\end{array}$ \\
\hline
\end{tabular}

\section{PENDAHULUAN}

Diabetes Mellitus (DM) adalah penyakit kronis yang kompleks membutuhkan perawatan medis berkelanjutan dengan strategi pengurangan risiko multifaktorial di luar kendali glikemik. Pendidikan manajemen diri pasien yang berkelanjutan dan dukungan sangat penting untuk mencegah komplikasi akut dan mengurangi risiko komplikasi jangka panjang [1].

Menurut WHO secara global ada 422 juta orang dewasa yang berusia di atas 18 tahun hidup dengan diabetes pada tahun 2014 . Jumlah terbesar orang dengan diabetes diperkirakan berasal dari Asia Tenggara dan Pasifik Barat. Jumlah peningkatan yang cukup besar terjadi dari tahun 1980-2014 meningkat dari 108 juta menjadi 422 juta atau sekitar empat kali lipat. Di Indonesia hasil survey Riset Kesehatan Dasar (Riskesdas) menunjukan angka pravelensi meningkat sebanyak 0,5\% dari tahun 2013 sampai 2018 [2].

Menurut data [1] seperempat orang di atas usia 65 tahun menderita diabetes dan setengahnya orang dewasa tua menderita pradiabetes. Orang dewasa tua dengan diabetes memiliki tingkat kematian dini yang lebih tinggi, cacat fungsional, kehilangan otot yang dipercepat, serta memiliki potensi penyakit penyerta lebih

Corresponding author:

Yuli Wahyuni

yuli.wahyuni@unpad.ac.id

Media Keperawatan Indonesia, Vol 4 No 3, August 2021

e-ISSN: 2615-1669

ISSN: 2722-2802

DOI: $10.26714 / \mathrm{mki} \cdot 4.3 .2021 .234-246$ 
tinggi, seperti hipertensi, penyakit jantung koroner, dan stroke. Selain itu orang dewasa tua dengan diabetes juga berisiko lebih besar memiliki sindrom geriatri, seperti polifarmasi, gangguan kognitif, depresi, inkontinensia urin, resiko jatuh, dan sakit yang terus-menerus. Jika hal tersebut dibiarkan tidak tertangani, kondisi tersebut akan mempengaruhi kemampuan dan kualitas manajemen diri serta kualitas hidup.

Komplikasi diabetes melitus dapat menyebabkan penyakit yang serius yang dapat mempengaruhi kualitas hidup. Kualitas hidup mengacu pada persepsi individu seseorang tentang status fisik, emosional, dan sosial [3]. Konsep kualitas hidup sering digunakan dalam penelitian klinis untuk menilai hasil perawatan dan pengobatan. Selain itu, literatur melaporkan kualitas hidup sebagai prediktor pemanfaatan layanan kesehatan yang optimal. Kualitas Hidup Terkait Kesehatan adalah konstruksi multidimensi yang meliputi dimensi fisik, kognitif, emosional, psikologis dan spiritual seseorang terhadap status kesehatan saat ini [4].

Hasil penelitian yang beragam tentang kualitas hidup pasien DM tipe 2 ditunjukkan dalam penelitian di tiga negara bagian yang berbeda yaitu di Malaysia,India dan Cina. Penelitian di Cina melaporkan kualitas hidup lebih rendahdibandingkan dengan Malaysia dan India [5]. Faktor-faktor yang dapat mempengaruhi kualitas hidup yaitu latihan fisik, frekuensi pemeriksaan glukosa, komplikasi, hipertensi, durasi diabetes, diet, dan depresi [3]. Penelitian lain yang serupa melaporkan adanya hubungan yang kuat antara usia, pendidikan, status perkawinan, BMI, HbA1c, kepatuhan, dan kepuasan pengobatan dalam model prediksi untuk meningkatkan kualitas hidup pada pasien DM tipe 2 [6]. Selanjutnya penelitian lain menyebutkan bahwa kepatuhan pengobatan merupakan faktor yang paling mempengaruhi kualitas hidup [4]. Kepatuhan dikaitkan dengan kemungkinan rawat inap yang menurun dan kunjungan gawat darurat lebih rendah dan lama rawat inap yang lebih pendek. Pasien dengan kepatuhan pengobatan yang tinggi juga mempunyai kemungkinan kecil untuk didiagnosis dengan komplikasi akut dalam periode tiga tahun [7].

Tujuan dari perawatan DM bukan hanya tindakan kuratif yang dapat memberikan perkiraan yang baik untuk pengendalian penyakit, tetapi tujuan akhir dari perawatan diabetes adalah mencegah kualitas hidup pasien menjadi lebih buruk [4]. Penelitian untuk memahami prediktor dan mengidentifikasi faktor-faktor yang mempengaruhi kualitas hidup menjadi penting agar dapat dijadikan dasar dalam program pengendalian dan pencegahan [8]. Oleh karena itu penelitian ini bertujuan untuk mengidentifikasi seberapa jauh kepatuhan pengobatan dapat mempengaruhi kualitas hidup pasien DM tipe 2 .

\section{METODE}

Metode pencarian literatur menggunakan database Pubmed, Science Direct, Cinahl, Willey Online Library dan google scholar dalam rentang waktu 2016-2021. Pencarian artikel menggunakan keyword dan boolean operator (AND dan OR) untuk menspesifikan pencarian, kata kunci disesuaikan dengan Medical Subject Heading (MeSH). Adapun kata kunci yang didapatkan adalah sebagai berikut Diabetes Mellitus Type 2 OR Diabetes Mellitus OR NIDDM OR Noninsulin-Dependent OR Diabetes Mellitus Type II AND (Treatment adherence OR Therapeutic Adherence and Compliance OR Adherence OR Therapeutic) AND (Quality of life OR Life Quality OR Health-Related Quality Of Life OR HRQOL). Hasil pencarian pada data base didapatkan 2.281 artikel (664 pada Pubmed, 203 pada Science Direct, 127 pada Chinal, 281 pada Willey Online Library dan 1133 pada google scholar). Peneliti kemudian melakukan skrining berdasarkan tahun publikasi, bahasa yang digunakan, artikel full teks, dan 
didapatkan sebanyak 213 artikel. Kemudian dianalisis lagi sesuai dengan kriteria inklusi dan eksklusi diperoleh 9 artikel. Adapun kriteria inklusi dan ekslusi mengacu pada PICO framework yaitu Populasinya pasien DM type 2, intervensi yang digunakan kepatuhan pengobatan, fokus kualitas hidup, sumber dari literature jelas dan terindex. Kriteria eksklusi adalah penelitian yang tidak menunjukan adanya hubungan antara kepatuhan pengobatan dan kualitas hidup, artikel tidak full teks, artikel yang duplikasi dan artikel yang tidak sesuai dengan topik ini. Untuk lebih lengkapnya dapat dilihat pada (Gambar 1).

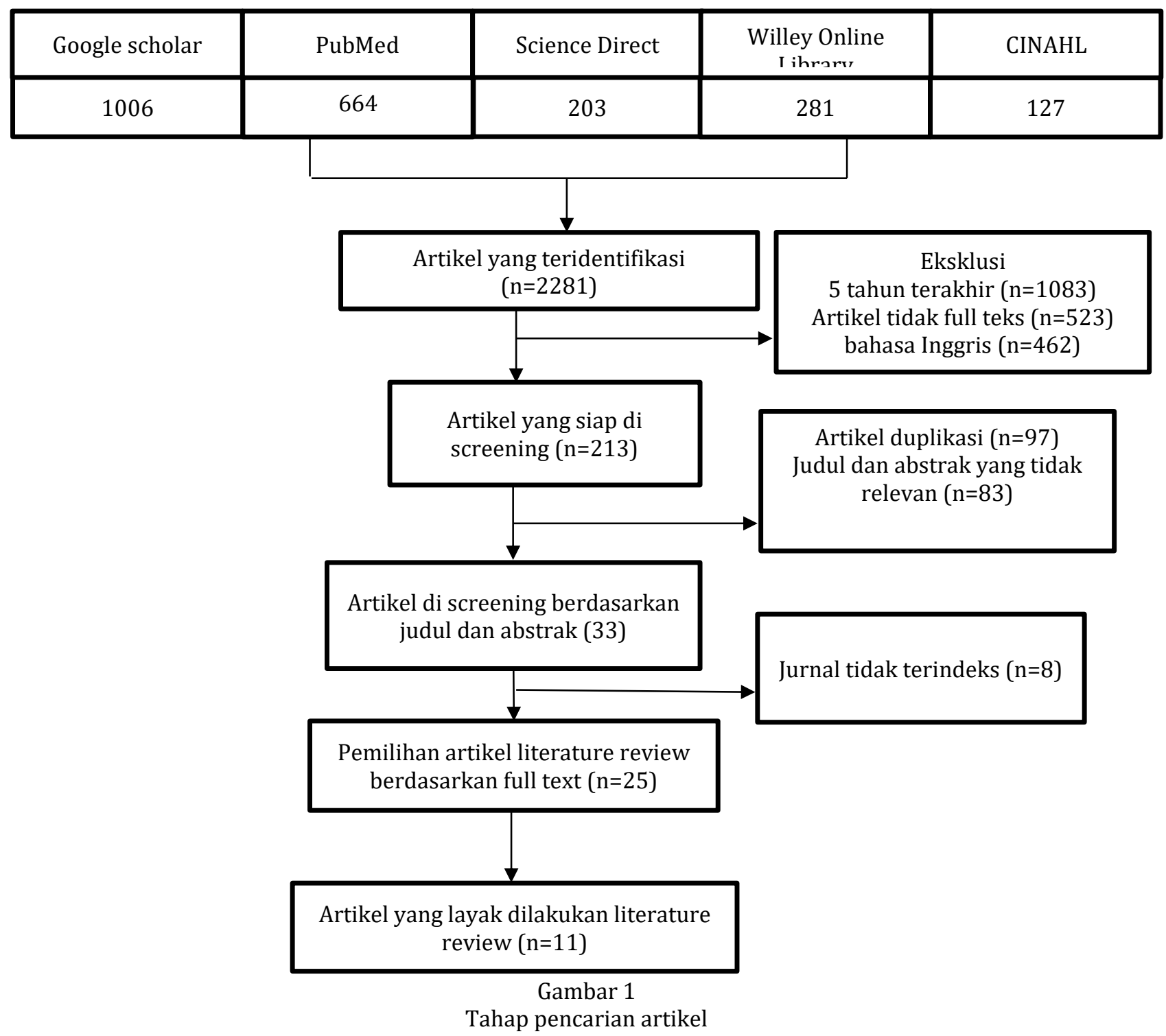

\section{HASIL}

Kualitas hidup pasien DM tipe 2 secara signifikan terkait dengan usia, durasi penyakit, jumlah obat yang diresepkan, kepatuhan pengobatan dan kepuasan pengobatan. Dari semua faktor yang mempengaruhi kualitas hidup pasien DM tipe 2, kepatuhan pengobatan dilaporkan sebagai prediktor signifikan, peningkatan satu skor kepatuhan dikaitkan dengan peningkatan kualitas hidup. Adapun faktor demografi yang dapat mempengaruhi kepatuhan adalah usia, pendidikan, dan jenis kelamin. Akan tetapi hubungan faktor demografi tersebut dengan kepatuhan tidak signifikan[4]. 
Kepatuhan pengobatan merupakan salah satu indikator dalam meningkatkan kualitas hidup pasien DM tipe 2. Kepatuhan pengobatan juga berpengaruh langsung terhadap diabetes distress, perilaku perawatan diri dan komplikasi diabetes. Pasien yang mempunyai kepatuhan pengobatan yang tinggi akan lebih sedikit mengalami diabetes distress dan akan memiliki kualitas hidup yang lebih baik. Kegiatan perawatan diri diabetes harus ditekankan untuk menurunkan diabetes distress dan meningkatkan kualitas hidup secara keseluruhan [9]. Depresi adalah hal yang umum di antara pasien DM Tipe 2 dan berhubungan dengan persepsi kualitas hidup yang buruk. Depresi harus diskrining terutama pada pasien yang lebih tua, yang menghadapi risiko lebih besar terkait dengan kurangnya motivasi dan kelelahan emosional. Perawatan psikologis dan farmakologis dari depresi pada pasien DM tipe 2 dikaitkan dengan perbaikan klinis yang signifikan. Perbaikan tersebut terjadi tidak hanya dalam suasana hati tetapi juga dalam kepatuhan terhadap diet dan rejimen pengobatan untuk pasien DM tipe 2, sehingga berdampak pada kontrol glikemik, mengurangi komplikasi kronis dan meningkatkan kualitas hidup [10].

Kepatuhan dan efikasi diri mempunyai hubungan yang sangat kuat terhadap kualitas hidup pasien DM tipe 2. Semakin baik efikasi diri maka semakin baik pula kepatuhan pada pasien DM tipe 2. Efikasi diri akan mempengaruhi pasien dalam berperilaku dan berkomitmen, sehingga dengan efikasi diri yang baik tujuan dari perubahan perilaku dapat tercapai. Efikasi diri yang paling baik pada hasil penelitian berturut-turut yaitu efikasi diri pada pengobatan DM, efikasi diri dalam mempertahankan berat badan, perawatan kaki, diet, memeriksakan gula darah, mengembalikan gula darah dalam batas normal, dan olahraga. Tujuan dari pengelolaan DM tidak akan tercapai tanpa disertai dengan kepatuhan pasien. Perilaku kepatuhan pada pasien DM tipe 2 meliputi pemantauan glukosa darah di rumah, pengaturan asupan makanan sehari-hari di rumah atau diet, mengelola pengobatan di rumah, melakukan aktivitas fisik yang dianjurkan, dan perawatan kaki. Kepatuhan dalam pengobatan DM dilakukan dengan melibatkan pasien secara aktif dalam pengelolaan penyakitnya, serta melakukan pembagian tugas antara tenaga kesehatan dan pasien sehingga keduanya memiliki peran yang sama dalam pengelolaan penyakit. Dengan demikian kepatuhan pengobatan merupakan faktor penting untuk meningkatkan kualitas hidup pasien DM tipe 2 [11].

Kepatuhan pengobatan terbukti dapat menurunkan rasa sakit dan komplikasi DM tipe 2, meningkatkan hasil klinis dan mengurangi tingkat morbiditas dan mortalitas. Hambatan dalam meningkatkan kualitas hidup pasien DM tipe 2 adalah kepatuhan pengobatan yang buruk, kurangnya pemahaman terhadap instruksi pengobatan, dan status ekonomi. Selain dari itu kepatuhan pengobatan yang rendah dipengaruhi oleh prediktor pengobatan komplementer dan alternatif [12]. Kepatuhan pengobatan dapat ditingkatkan melalui kualitas perawatan. Kualitas perawatan dengan pelayanan kesehatan terpadu dari petugas kesehatan yang membantu pasien beradaptasi dengan penyakit dan pengobatannya. Pemahaman pasien tentang pengobatan juga dapat meningkatkan kepatuhan pengobatan. Salah satu pemahaman pengobatan yang salah adalah perasaan takut pasien terhadap efek samping dari pengobatan yang ditemukan sebagai salah satu prediktor yang menurunkan kepatuhan pengobatan. Selain dari itu penurunan kepatuhan berhubungan dengan politerapi, Akan tetapi faktor ini dapat dimodifikasi dengan mengubah pengobatan menjadi rejimen sederhana yang dapat dikelola oleh pasien. Adapun untuk faktor jenis kelamin dan usia merupakan salah satu faktor yang tidak dapat dirubah yang mempengaruhi kepatuhan pengobatan dan kualitas hidup [13]. 
Selain dari itu pengaruh aspek religiusitas terhadap kepatuhan pengobatan dan kualitas hidup terjadi melalui mediator koping religious dan dukungan sosial. Religiusitas menunjukkan efek langsung dan tidak langsung pada kepatuhan pengobatan. Pengembangan keterampilan koping religious dan mempromosikan dukungan sosial dapat efektif untuk meningkatkan kepatuhan pengobatan pada pasien diabetes. Pengaruh interaksi yang signifikan antara koping religious dan dukungan sosial pada kepatuhan pengobatan juga dapat menunjukkan pentingnya menerapkan intervensi menggunakan aspek tersebut secara bersamaan [14].

Salah satu program yang terbukti dapat meningkatkan kepatuhan dan kualitas hidup pasien DM tipe 2 adalah program pendidikan diabetes yang berorientasi pada keluarga. Program Pendidikan yang berorientasi pada keluraga ini dapat meningkatkan meningkatkan efikasi diri dan manajemen diri yang penting untuk mengurangi komplikasi yang terkait dengan diabetes. Program berorientasi keluarga ini dilakukan dalam budaya yang memiliki ikatan kekeluargaan dan kekerabatan yang kuat. Dukungan keluarga merupakan sumber lain yang dapat membantu pasien DM tipe 2 untuk meningkatkan aktivitas perawatan diri dan temuan ini mendukung manfaat tambahan yang dicapai dengan mengikutsertakan keluarga dalam program pendidikan yaitu keluarga dapat memberikan dukungan fisik, mental dan sosial ekonomi kepada pasien DM tipe 2 [15]. Selain itu kepatuhan yang tinggi terhadap MedDiet pada pasien DM tipe 2 dikaitkan dengan kepuasan pengobatan diabetes dan kualitas hidup yang lebih tinggi. MedDiet adalah referensi sebagai pola makan sehat dan juga merupakan pendekatan diet yang cocok untuk pengelolaan diabetes. MedDiet, juga merupakan bagian integral dari terapi nutrisi medis pasien dengan DMT2, berkontribusi pada kontrol parameter metabolik [16],

Dari sembilan artikel yang direview, kualitas hidup pasien DM Tipe 2 yang tinggi berhubungan dengan kepatuhan pengobatan yang tinggi pula. Kepatuhan pengobatan mempunyai efek yang positif terhadap efikasi diri, manajemen diri dan diabetes distress. Kepatuhan pengobatan telah terbukti dapat menurunkan komplikasi diabetes, mortalitas, morbiditas dan meningkatkan kualitas hidup. Upaya untuk meningkatkan kepatuhan pengobatan dapat dicapai melalui peningkatan kualitas perawatan penyedia layanan kesehatan, koping religious dan dukungan sosial, pemahaman tentang pengobatan, program berorientasi keluarga dan kepatuhan pada MedDiet.

Tabel 1

Matriks Sintesis

\begin{tabular}{|c|c|c|c|}
\hline Author & Judul & $\begin{array}{c}\text { Method dan } \\
\text { sample }\end{array}$ & Hasil \\
\hline $\begin{array}{l}\text { (Iqbal, Ul Haq, } \\
\text { Bashir, \& Bashaar, } \\
\text { 2017) }\end{array}$ & $\begin{array}{l}\text { Profile } \\
\text { predictors and } \\
\text { health related } \\
\text { quality of life } \\
\text { among type II } \\
\text { diabetes mellitus } \\
\text { patients in Quetta } \\
\text { city, Pakistan }\end{array}$ & $\begin{array}{l}\text { Matode penelitian } \\
\text { ini menggunakan } \\
\text { cross sectional. } \\
\text { Jumlah sampel } \\
\text { yaitu } 300 \text { pasien } \\
\text { diabetes tipe II } \\
\text { yang mendatangi } \\
\text { rumah sakit } \\
\text { umum dan swasta } \\
\text { di Pakistan }\end{array}$ & $\begin{array}{l}\text { Ditemukan kualitas hidup yang buruk dengan } \\
\text { skor rata-rata } 0,48 \pm 0,36 \text {. Usia, durasi penyakit, } \\
\text { jumlah obat yang diresepkan, kepatuhan } \\
\text { pengobatan dan kepuasan pengobatan secara } \\
\text { signifikan terkait (p <0,05) dengan HRQoL } \\
\text { dalam analisis tabulasi silang. Variabel yang } \\
\text { signifikan dimasukkan ke dalam model yang } \\
\text { menunjukkan goodness of fit yang signifikan } \\
\text { dengan Omnibus Test of Model Coefficient yang } \\
\text { sangat signifikan (Chi-square = } 12,983 \text {, p = } \\
0,030 \text {, df = 4). Kepatuhan obat dilaporkan } \\
\text { sebagai prediktor signifikan HRQoL dengan } \\
\text { peningkatan satu skor kepatuhan dikaitkan }\end{array}$ \\
\hline
\end{tabular}




\begin{tabular}{|c|c|c|c|}
\hline Author & Judul & $\begin{array}{c}\text { Method dan } \\
\text { sample }\end{array}$ & Hasil \\
\hline & & & $\begin{array}{l}\text { dengan peningkatan HRQoL dengan faktor } 1,75 \\
\text { asalkan variabel lain tetap konstan. }\end{array}$ \\
\hline $\begin{array}{l}\text { (Saffari, Lin, Chen, } \\
\text { \& Pakpour, 2019) }\end{array}$ & $\begin{array}{l}\text { Health and quality } \\
\text { of life outcomes } \\
\text { impairment of } \\
\text { quality of life in } \\
\text { type } 2 \\
\text { diabetes mellitus: } \\
\text { a cross-sectional } \\
\text { study }\end{array}$ & $\begin{array}{l}\text { Penelitian ini } \\
\text { menggunakan } \\
\text { metode studi } \\
\text { longitudinal, } \\
\text { Jumlah sampel } \\
\text { adalah } 793 \text { orang } \\
\text { dewasa ( } 65 \\
\text { tahun, } 45 \% \\
\text { perempuan) } \\
\text { direkrut dari } 4 \\
\text { pusat perawatan } \\
\text { diabetes dari } \\
\text { tahun 2015-2017 } \\
\text { dan diikuti } \\
\text { selama } 1 \text { tahun. }\end{array}$ & $\begin{array}{l}\text { Hasil Koping agama dan dukungan sosial diakui } \\
\text { sebagai mediator yang signifikan antara } \\
\text { religiusitas dan kepatuhan pengobatan (CFI = } \\
0,983 \text {, TLI }=0,985 \text {, dan RMSEA = 0,021). } \\
\text { Hubungan antara religiusitas dan HRQoL sangat } \\
\text { dimediasi oleh dukungan sosial, koping agama } \\
\text { dan kepatuhan pengobatan dan variabel- } \\
\text { variabel ini masing-masing menjelaskan } 12 \% \\
\text { dan } 33 \% \text { varian HRQoL generik dan spesifik. } \\
\text { Tidak ada pengaruh langsung yang signifikan } \\
\text { dari religiusitas pada HRQoL. HbA1c dan kadar } \\
\text { glukosa darah puasa berhasil dimuat pada } \\
\text { konstruksi laten kepatuhan pengobatan (faktor } \\
\text { loading = 0,51 dan 0,44, masing-masing). } \\
\text { Kesimpulannya Dampak religiusitas terhadap } \\
\text { kepatuhan pengobatan dan HRQoL terjadi } \\
\text { melalui mediator seperti religius coping dan } \\
\text { dukungan sosial. Oleh karena itu, untuk } \\
\text { meningkatkan kepatuhan terhadap pengobatan } \\
\text { dan kualitas hidup, intervensi dapat dirancang } \\
\text { berdasarkan mediatorini. }\end{array}$ \\
\hline $\begin{array}{l}\text { (Jannoo, Wah, } \\
\text { Lazim, \& Hassali, } \\
\text { 2017) }\end{array}$ & $\begin{array}{l}\text { Examining } \\
\text { diabetes distress, } \\
\text { medication } \\
\text { adherence, } \\
\text { diabetes self-care } \\
\text { activities, } \\
\text { diabetes-specific } \\
\text { quality of life and } \\
\text { health-related } \\
\text { quality of life } \\
\text { among type } 2 \\
\text { diabetes mellitus } \\
\text { patients }\end{array}$ & $\begin{array}{l}\text { Penelitian } \\
\text { menggunakan } \\
\text { metode cross- } \\
\text { sectional, dengan } \\
\text { jumlah } \\
\text { responden pasien } \\
\text { DM tipe } 2 \\
\text { sebanyak } 97 \\
\text { orang dari klinik } \\
\text { rawat jalan di tiga } \\
\text { rumah sakit } \\
\text { umum dan satu } \\
\text { klinik } \\
\text { pemerintah. } \\
\text { Pengujian model } \\
\text { hipotesis } \\
\text { menggunakan } \\
\text { analisis Structural } \\
\text { Equation } \\
\text { Modeling (SEM) }\end{array}$ & $\begin{array}{l}\text { Hasil SEM menunjukkan kepatuhan minum obat } \\
\text { (MMAS) berpengaruh langsung signifikan } \\
\text { terhadap diabetes distress (PAID) (Beta = - } \\
0.20 \text { ). Konstruksi kegiatan perawatan diri } \\
\text { (SDSCA) secara signifikan terkait dengan } \\
\text { diabetes distress (PAID) (Beta }=-0.24 \text { ). } \\
\text { Konstruksi kegiatan perawatan diri (SDSCA) } \\
\text { ditemukan memiliki hubungan yang signifikan } \\
\text { dengan HRQoL (SF-36) (Beta =0.11). Selain itu, } \\
\text { gangguan diabetes memiliki efek yang } \\
\text { signifikan (Beta }=-0,11 \text { ) pada HRQoL pasien. } \\
\text { Akhirnya, ADDQoL memiliki pengaruh yang } \\
\text { signifikan terhadap HRQoL (Beta = 0.12) }\end{array}$ \\
\hline $\begin{array}{l}\text { (Handono } \\
\text { Fatkhur Rahman, } \\
\text { H. F., \& } \\
\text { Sukmarini, Y. L., } \\
\text { 2017) }\end{array}$ & $\begin{array}{l}\text { (Self Efficacy, } \\
\text { Adherence, and } \\
\text { Quality of Life of } \\
\text { Patients with } \\
\text { Type 2 Diabetes) }\end{array}$ & $\begin{array}{lr}\text { Desain } & \text { dalam } \\
\text { penelitian } & \text { ini } \\
\text { adalah } & \text { cross } \\
\text { sectional, dengan } \\
\text { jumlah } \\
125 \text { pampel } \\
\text { tipe } 2 .\end{array}$ & $\begin{array}{l}\text { Hasil penelitian menunjukkan } \\
\text { bahwa efikasi diri }(0,0005) \text {, dan kepatuhan } \\
(0,0005) \text { berhubungan secara signifikan dengan } \\
\text { kualitas hidup dengan variabel yang paling } \\
\text { dominan adalah kepatuhan. Hasil uji multivariat } \\
\text { menunjukkan bahwa variabel efikasi diri, } \\
\text { kepatuhan, depresi, dan tingkat pendidikan } \\
\text { menentukan kualitas hidup pasien DM. } \\
\text { Perlunya dikembangkan pengkajian dan } \\
\text { intervensi } \\
\text { keperawatan yang berfokus pada efikasi diri } \\
\text { dan kepatuhan pasien DM tipe } 2 \text {. }\end{array}$ \\
\hline $\begin{array}{l}\text { (Alfian, Sukandar, } \\
\text { Lestari, \& } \\
\text { Abdulah, 2016) }\end{array}$ & $\begin{array}{l}\text { Medication } \\
\text { Adherence }\end{array}$ & $\begin{array}{l}\text { Penelitian ini } \\
\text { menggunakan } \\
\text { metode Cross }\end{array}$ & $\begin{array}{l}\text { Hasil penelitian menunjukkan bahwa } 49,4 \% \\
\text { menunjukkan kepatuhan rendah, } 29,7 \% \\
\text { menunjukkan kepatuhan sedang, dan } 20,9 \%\end{array}$ \\
\hline
\end{tabular}




\begin{tabular}{|c|c|c|c|}
\hline Author & Judul & $\begin{array}{l}\text { Method dan } \\
\text { sample }\end{array}$ & Hasil \\
\hline & $\begin{array}{l}\text { Contributes to an } \\
\text { Improved } \\
\text { Quality of Life in } \\
\text { Type } 2 \text { Diabetes } \\
\text { Mellitus Patients: } \\
\text { A Cross-Sectional } \\
\text { Study }\end{array}$ & $\begin{array}{l}\text { sectional dengan } \\
\text { jumlah sampel } 91 \\
\text { orang yang } \\
\text { menghadiri } \\
\text { fasiltas Kesehatan } \\
\text { sekunder di Kota } \\
\text { Bandung }\end{array}$ & $\begin{array}{l}\text { menunjukkan kepatuhan tinggi terhadap } \\
\text { diabetes } \\
\text { pengobatan. QOL spesifik diabetes terbukti } \\
\text { sangat terpengaruh dalam domain fungsi } \\
\text { seksual. Skor domain beban sosial adalah } \\
\text { lebih baik dari skor QOL keseluruhan. Ada } \\
\text { hubungan yang signifikan antara kepatuhan dan } \\
\text { QOL spesifik diabetes (p = 0,009). } \\
\text { Hasil tes menggunakan post hoc Mann - } \\
\text { Whitney (kepatuhan tinggi vs. } \\
\text { kepatuhan sedang, }=0,084 \text {; kepatuhan sedang } \\
\text { vs } \\
\text { kepatuhan rendah, p = 0,86; dan kepatuhan } \\
\text { tinggi vs kepatuhan rendah, } \\
\text { p = 0,001) menunjukkan bahwa kepatuhan } \\
\text { pengobatan berkontribusi terhadap } \\
\text { QOL yang lebih baik. Analisis regresi berganda } \\
\text { menunjukkan bahwa prediktor diabetes } \\
\text { spesifik } \\
\text { Kualitas hidup adalah kepatuhan dan } \\
\text { pendapatan pasien. } \\
\text { Kesimpulan: Kepatuhan yang pengobatan } \\
\text { menunjukkan efek positif pada } \\
\text { QOL spesifik diabetes. Pasien dengan } \\
\text { kepatuhan yang tinggi terhadap pengobatan } \\
\text { memiliki QOL yang lebih baik. Hasil ini penting } \\
\text { dalam mengembangkan program intervensi } \\
\text { untuk pasien tetapi juga dalam meningkatkan kualitas } \\
\text { hidup mereka melalui promosi kesehatan yang } \\
\text { berkelanjutan. }\end{array}$ \\
\hline $\begin{array}{l}\text { (Perwitasari \& } \\
\text { Urbayatun, 2016) }\end{array}$ & $\begin{array}{l}\text { Treatment } \\
\text { Adherence and } \\
\text { Quality of Life in } \\
\text { Diabetes Mellitus } \\
\text { Patients in } \\
\text { Indonesia }\end{array}$ & \begin{tabular}{lr}
\multicolumn{2}{l}{ Penelitian } \\
menggunakan \\
cross & sectional \\
dengan & 65 \\
responden pasien \\
DM
\end{tabular} & $\begin{array}{l}\text { Dari seluruh responden yang memenuhi } \\
\text { kriteria inklusi tidak ada yang signifikan } \\
\text { perbedaan skrining BMQ dan fungsi DQLCTQ } \\
\text { antara kelompok monoterapi dan terapi } \\
\text { kombinasi ( } p>.05 \text { ). Skor skrining BMQ pada } \\
\text { terapi kombinasi lebih tinggi dibandingkan } \\
\text { dengan kelompok monoterapi. Fungsi fisik, } \\
\text { gangguan kesehatan, dan kesehatan mental } \\
\text { kelompok terapi kombinasi lebih tinggi } \\
\text { daripada kelompok monoterapi. Pasien laki-laki } \\
\text { sudah signifikan skor domain rejimen BMQ } \\
\text { yang lebih tinggi daripada pasien wanita } \\
\text { (masing-masing 0,35 dan 0,17). Usia yang lebih } \\
\text { tua memiliki skor yang lebih rendah efek } \\
\text { pengobatan DQLCTQ ( } p<.05 \text { ). Keyakinan, } \\
\text { ingatan, dan keyakinan tentang reaksi obat } \\
\text { merugikan dari BMQ memiliki hasil positif } \\
\text { korelasi dengan fungsi fisik ( } r=.542, .424 \text {, dan } \\
.640 \text {, masing-masing). Studi kami } \\
\text { menyimpulkan bahwa kualitas perawatan, jenis } \\
\text { kelamin,dan usia dapat memprediksi kepatuhan } \\
\text { dan kualitas hidup pasien. Ada korelasi positif } \\
\text { antara kepatuhan pasien dan kualitas hidup. }\end{array}$ \\
\hline $\begin{array}{l}\text { (Wichit, } \\
\text { Mnatzaganian, } \\
\text { Courtney, Schulz, } \\
\text { \& Johnson, 2017) }\end{array}$ & $\begin{array}{l}\text { Randomized } \\
\text { controlled trial of } \\
\text { a family-oriented } \\
\text { self-management }\end{array}$ & $\begin{array}{l}\text { Penelitian ini } \\
\text { menggunakan } \\
\text { metode } \\
\text { randomized }\end{array}$ & $\begin{array}{l}\text { Tidak ada perbedaan signifikan antara } \\
\text { kelompok yang diamati pada semua } \\
\text { karakteristik awal kecuali usia. Efikasi diri } \\
\text { diabetes, manajemen diri, dan kualitas hidup }\end{array}$ \\
\hline
\end{tabular}




\begin{tabular}{|c|c|c|c|}
\hline Author & Judul & $\begin{array}{c}\text { Method dan } \\
\text { sample } \\
\end{array}$ & Hasil \\
\hline & $\begin{array}{l}\text { program to } \\
\text { improve self- } \\
\text { efficacy, glycemic } \\
\text { control and quality } \\
\text { of life among Thai } \\
\text { individuals with } \\
\text { Type 2 diabetes }\end{array}$ & $\begin{array}{l}\text { controlled trial } \\
\text { dengan } 140 \text { orang } \\
\text { responden } \\
\text { diabetes tipe } 2 \\
\text { dan } \\
\text { dikelompokan } \\
\text { secara acak untuk } \\
\text { kelompok } \\
\text { intervensi dan } \\
\text { kontrol, yang } \\
\text { direkrut dari } \\
\text { klinik diabetes di } \\
\text { Thailand, }\end{array}$ & $\begin{array}{l}\text { meningkat pada kelompok intervensi tetapi } \\
\text { tidak ada perbaikan yang diamati pada } \\
\text { kelompok kontrol. Dalam model multivariabel } \\
\text { yang disesuaikan dengan risiko, dibandingkan } \\
\text { dengan kontrol, kelompok intervensi memiliki } \\
\text { efikasi diri, manajemen diri, ekspektasi hasil, } \\
\text { dan pengetahuan diabetes yang lebih baik } \\
\text { secara signifikan (p <0,001, masing-masing). } \\
\text { Partisipasi dalam intervensi meningkatkan skor } \\
\text { manajemen diri diabetes sebesar } 14,3 \text { poin (b = } \\
\text { 14,3, (95\% CI 10,7-17,9), p <0,001). Manajemen } \\
\text { diri lebih baik pada pasien yang lebih kurus dan } \\
\text { pada wanita. Tidak ada perbedaan antara } \\
\text { kelompok yang terlihat dalam kualitas hidup } \\
\text { atau kontrol glikemik, namun, dalam model } \\
\text { multivariabel yang disesuaikan dengan risiko, } \\
\text { skor manajemen diri yang lebih tinggi dikaitkan } \\
\text { dengan penurunan signifikan kadar HbA1c (p } \\
<0,001 \text { ) dan peningkatan kualitas hidup pasien } \\
\text { (p <0,001). <0,05) (terlepas dari keanggotaan } \\
\text { grup). Kesimpulan: Program berorientasi } \\
\text { keluarga kami meningkatkan efikasi diri dan } \\
\text { manajemen diri pasien, yang pada gilirannya } \\
\text { dapat menurunkan kadar HbA1c. }\end{array}$ \\
\hline $\begin{array}{l}\text { (Zurita-Cruz et al., } \\
\text { 2018) }\end{array}$ & $\begin{array}{l}\text { Health and quality } \\
\text { of life outcomes } \\
\text { impairment of } \\
\text { quality of life in } \\
\text { type } 2 \text { diabetes } \\
\text { mellitus: a cross- } \\
\text { sectional study }\end{array}$ & $\begin{array}{lr}\text { Penelitian } & \text { ini } \\
\text { menggunakan } \\
\text { metode } & \text { cross- } \\
\text { sectional } & \text { study } \\
\text { dengan } & \text { total } \\
\text { responden } & 1.394 \\
\text { pasien } & \end{array}$ & $\begin{array}{l}\text { Di antara } 1.394 \text { pasien yang dilibatkan, usia } \\
\text { rata-rata adalah } 62 \text { tahun. HRQoL global } \\
\text { memiliki median } 50,1 \text { poin. } \\
\text { Analisis bivariat menunjukkan bahwa umur, } \\
\text { status perkawinan, jenis kelamin, pekerjaan, } \\
\text { penyakit penyerta, lamanya DM2 dan penyakit } \\
\text { penyerta berdampak pada HRQoL. Model } \\
\text { regresi logistik mengidentifikasi usia (rasio } \\
\text { odds [OR] 1,04) dan depresi (OR 4,4) sebagai } \\
\text { faktor independen yang mempengaruhi kualitas } \\
\text { hidup secara keseluruhan. }\end{array}$ \\
\hline $\begin{array}{l}\text { (Alcubierre et al., } \\
\text { 2016) } \\
\text { Tabel }\end{array}$ & $\begin{array}{l}\text { Relationship of the } \\
\text { adherence to the } \\
\text { Mediterranean } \\
\text { diet with health- } \\
\text { related } \\
\text { quality of life and } \\
\text { treatment } \\
\text { satisfaction in } \\
\text { patients with type } \\
2 \text { diabetes } \\
\text { mellitus: a } \\
\text { post-hoc analysis } \\
\text { of a cross- } \\
\text { sectional study }\end{array}$ & $\begin{array}{l}\text { Penelitian ini } \\
\text { menggunakan } \\
\text { cross-sectional } \\
\text { study dengan } \\
\text { melibatkan } 294 \\
\text { pasien dengan } \\
\text { DMT2 (146 } \\
\text { dengan retinopati } \\
\text { diabetik dan } 14 \\
\text { tanpa retinopati) }\end{array}$ & $\begin{array}{l}\text { Kepatuhan pada diet Mediterania tidak } \\
\text { menunjukkan hubungan yang signifikan dengan } \\
\text { kualitas hidup secara skor keseluruhan. Namun, } \\
\text { rMED dikaitkan dengan beberapa dimensi } \\
\text { HRQoL : perjalanan, kepercayaan diri, dan } \\
\text { kebebasan untuk makan dan minum ( } p=0,020 \text {, } \\
p=0,015, p=0,037 \text { dan } p=0,015) \text {. Mengenai } \\
\text { kepuasan pengobatan, rMED positif dengan } \\
\text { skor keseluruhannya ( } p=0,046) \text {, dan terutama } \\
\text { tentang pemahaman diabetes }(p=0,0004) \text { dan } \\
\text { rekomendasi pengobatan ( } p=0,036) \text {, serta } \\
\text { frekuensi hiperglikemia yang dirasakan ( } p= \\
0,039) \text {. }\end{array}$ \\
\hline
\end{tabular}


Analisis Sintesis literature review dijelaskan pada bagan dibawah ini :

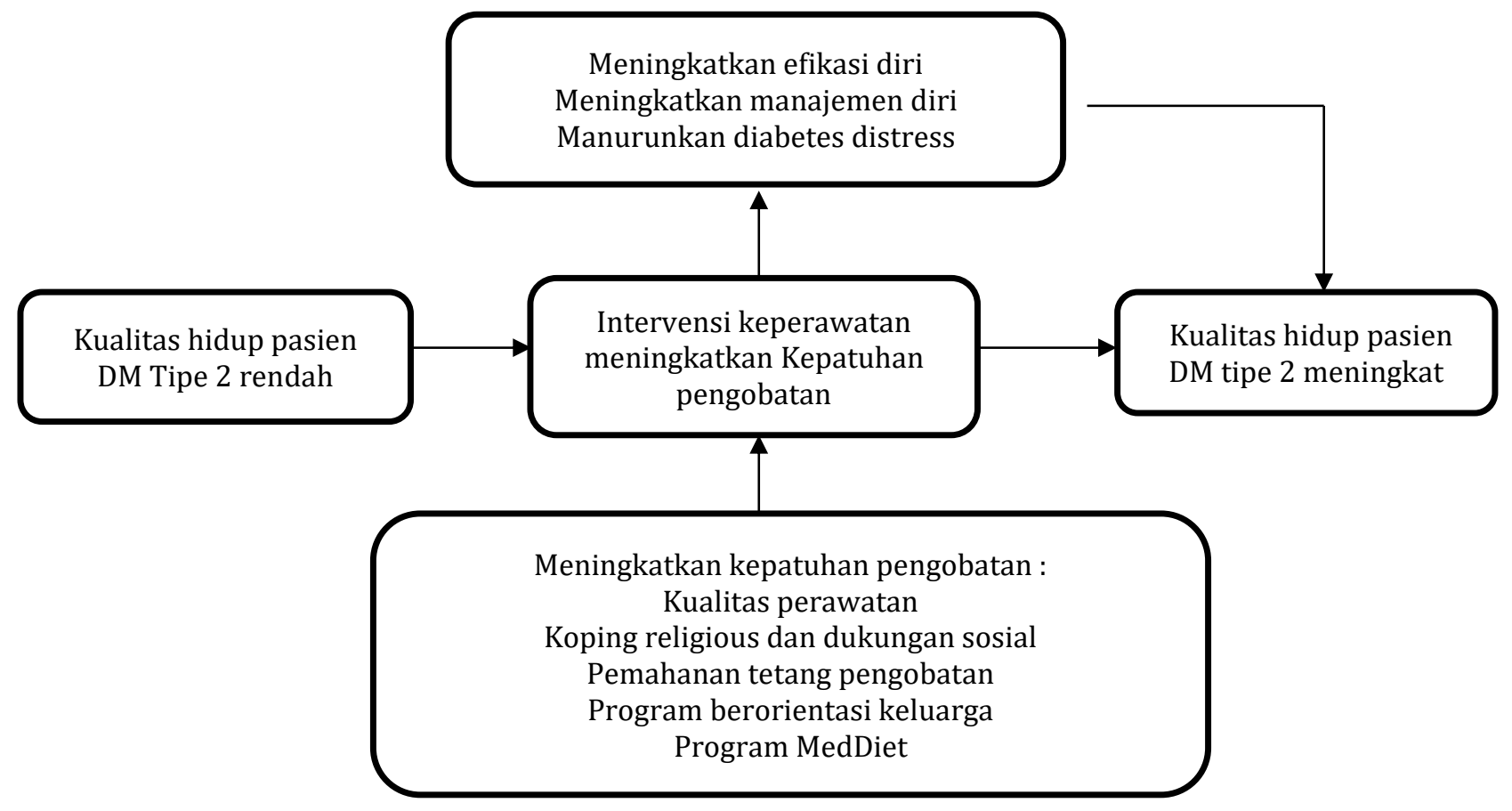

Gambar 2

Analisa sintesis meningkatkan kualitas hidup pasien DM tipe 2

\section{PEMBAHASAN}

Berdasarkan hasil review dari 9 artikel didapatkan bahwa kepatuhan berhubungan positif dengan peningkatan kualitas hidup pasien DM tipe 2. Kepatuhan pengobatan merupakan faktor yang paling berpengaruh dalam manajemen penyakit pada pasien DM tipe 2 [17]. Pada konsep Health Promotion Models (HPM) kepatuhan pasien terhadap perilaku yang positif akan berdampak pada tecapainya tujuan yang diinginkan. Pasien DM yang memiliki kepatuhan pengobatan yang tinggi dinilai mampu melakukan program pengelolaan DM dengan baik untuk mencapai kondisi pasien yang stabil [18].

Kepatuhan dalam pengelolaan DM akan berdampak terhadap peningkatan efikasi diri [11], manajemen diri [15] dan menurunkan diabetes distress $([9,10]$. Efikasi diri dan kepatuhan merupakan suatu hal yang saling berhubungan. Efikasi diri dalam perawatan diabetes merupakan faktor penting dalam merubah perilaku pasien DM tipe 2 sesuai dengan yang diharapkan dan dapat mendorong motivasi untuk mengikuti manajemen diabetes. Dengan demikian jika efikasi diri pasien baik maka manajemen diri pasien tersebut akan baik pula [18]. Pada penelitian sebelumnya dikatakan bahwa kepatuhan pengobatan dapat memprediksi diabetes distress lebih awal, sehingga diabetes distress dapat diantisipasi melaui strategi dengan berfokus pada intervensi untuk mengurangi diabetes distress[19]. Penelitian yang lain menjelaskan bahwa depresi dapat mengganggu kemampuan untuk memulai pola hidup sehat dan dapat meningkatkan kebiasaan makan yang buruk [20].

Selain dapat meningkatkan kualitas hidup pasien DM tipe 2 kepatuhan pengobatan juga dapat menurunkan komplikasi diabetes $[9,10,12]$, mortalitas, dan morbiditas [12]. Komplikasi diabetes mikro dan makrovaskuler pada pasien DM tipe 2 dikaitkan dengan peningkatan glukometabolik yang diakibatkan karena ketidakpatuhan pada manajemen pengobatan [21]. Penelitian lain 
menyebutkan bahwa kepatuhan pengobatan dapat meningkatkan hasil klinis dan mengurangi tingkat morbiditas dan mortalitas serta perkembangan penyakit. Komplikasi penyakit DM dapat dicegah dengan meningktakan kepatuhan pengobatan, karena kepatuhan pengobatan dapat menumbuhkan kesadaran diri untuk melakukan manajem DM dengan baik [22].

Meningkatkan kepatuhan pengobatan dapat dilakukan dengan cara meningkatkan kualitas perawatan [13], koping religius dan dukungan sosial [14], pemahaman tentang pengobatan [12], program berorientasi keluarga [15] dan program MedDiet [16]. Kualitas perawatan pelayanan kesehatan pasien DM dapat ditingkatkan melalui pendekatan multidisiplin dalam melaksanakan manajemen diabetes [23]. Diperlukan kerjasama dari berbagai tenaga kesehatan seperti dokter, perawat, apoteker dan psikolog untuk membantu pasien beradaptasi dengan penyakit dan pengobatannya. Kolaborasi dari penyedia pelayanan kesehatan yang baik akan menjadi motivasi untuk meningkatkan kepatuhan pasien [23]. Upaya untuk meningkatkan kepatuhan pasien juga dapat dilakukan dengan mengadopsi pendekatan seperti gaya komunikasi yang tidak menghakimi, memperhatikan masalah pasien, menyediakan dan melibatkan dukungan sosial yang relevan, mengurangi kerumitan pengobatan dan mengurangi jumlah obat untuk mendorong kepatuhan pengobatan [24].

Selanjutnya religiusitas dapat meningkatkan kepatuhan melalui mediator koping religius dan dukungan sosial. Religiusitas adalah konsep yang luas dalam memberikan pengaruhnya terhadap kepatuhan dan kualitas hidup [14]. Koping religius berperan dalam meningkatkan kepatuhan melalui interaksi sosial yang baik. Dalam konsep agama kesehatan merupakan hal yang penting dan menduduki nilai yang tinggi. Dengan demikian pasien perlu mencoba cara terbaik untuk memulihkan kesehatan salah satunya melalui kepatuhan pada pengobatan [25]. Selain itu dalam pendekatan agama saling membantu untuk orang yang membutuhkan merupakan suatu kewajiban [26]. Oleh karena itu pasien yang mempunyai tingkat religiusitas yang baik maka dapat diprediksi bahwa kepatuhan pengobatannya juga baik.

Pemahaman pasien DM tipe 2 tentang pengobatan yang benar dapat meningkatakan kepatuhan pengobatan. Upaya untuk meningkatkan pemahaman pasien tentang pengobatan yang benar dapat dilakukan dengan memberikan informasi penting termasuk apa yang harus dilakukan jika dosis terlewatkan atau efek samping disebabkan oleh obat yang diresepkan [12]. Penelitian lain menjelaskan bahwa promosi kesehatan tentang pengetahuan resep medis dapat efektif merubah sikap negatif pasien terhadap pengobatan. Penjelasan mengenai dampak pengobatan komplementer dan alternatif serta manfaat dari pengobatan medis juga dapat menigkatkan kepatuhan. Semakin bertambahnya pemahaman pasien mengenai pengobatan yang tepat maka akan mendorong sikap positif pasien terhadap kepatuhan pengobatan medis [27]. Oleh karena itu petugas kesehatan harus memberikan perhatian khusus pada perilaku minum obat pasien dan harus berupaya menjelaskan manfaat kepatuhan minum obat kepada pasien.

Peran dan keterlibatan keluarga terhadap kepatuhan pasien DM tipe 2 ini terbukti efektif dalam meningkatkan efikasi diri, manajemen diri, dan pengetahuan pasien tentang diabetes [15]. Program berorientasi keluarga pada pasien DM tipe 2 mempunyai peran yang sangat penting dalam menyediakan makanan dan manajemen diet, mendorong dan memantau latihan, pemantauan glukosa darah dan perilaku perawatan diri lainnya [28]. Selain dari keterlibatan keluarga MedDiet juga dapat meningkatkan kepatuhan dan kepuasan pengobatan. MedDiet merupakan bagian dari terapi nutrisi yang cocok bagi pasien 
DM tipe 2 [16]. Pada penelitian lain pasien yang mempunyai kepatuhan MedDiet tinggi lebih aktif secara fisik, memiliki kualitas hidup yang lebih baik dan konsumsi minuman beralkohol yang lebih rendah [29]. Penyedia layanan kesehatan diharapkan dapat menerapkan intervensi dengan melibatkan keluarga dalam manjemen DM dan memberikan pengetahuan tentang manajemen diet yang baik.

\section{SIMPULAN}

Kualitas hidup pasien DM tipe 2 dapat ditingkatkan dengan meningkatkan kepatuhan pasien terhadap pengobatan. Kepatuhan pengobatan dapat menurunkan mortalitas, morbiditas dan komplikasi penyakit melalui peningkatan efikasi diri dan manajemen diri dalam pengelolaan penyakit DM. Kepatuhan pengobatan juga dapat menurunkan diabetes distress karena dapat memeprediksi terjadinya lebih awal. Sehingga efek negatif dari diabetes distress seperti kebiasaan makan yang buruk dan ketidakmampuan untuk menjalankan pola hidup sehat tidak akan terjadi.

Kepatuhan dapat ditingkatkan melalui peningkatan kualitas perawatan, koping religius dan dukungan sosial, pemahaman tentang pengobatan, program berorientasi keluarga dan program MedDiet. Oleh karena itu dalam mengembangkan intervensi untuk meningkatkan kepatuhan petugas kesehatan harus memperhatikan aspek-aspek tersebut. Penyedia pelayanan kesehatan dapat meningkatkan pelayanan kesehatan terhadap manajemen DM melalui pendekatan multidisplin dari berbagai profesi, komunikasi yang baik, mengurangi kerumitan berobat dan mengurangi jumlah obat yang diberikan. Intervensi yang dapat dikembangkan dalam meningkatkan kepatuhan pasien adalah promosi kesehatan mengenai pemahaman pengobatan yang tepat, melibatkan keluarga dalam pengobatan pasien DM, dan memberikan pendidikan kesehatan tentang diet DM yang tepat.

\section{UCAPAN TERIMA KASIH}

Penulis mengucapkan terima kasih kepada semua pihak yang telah mendukung penulisan literatur review ini.

\section{REFERENSI}

[1] American Diabetes Association. 16. Diabetes Advocacy: Standards of Medical Care in Diabetes-2019. Diabetes Care 2020;43:S203-4. Https://doi.org/10.2337/dc20-S016.

[2] Infodatin (Pusat Data dan Informasi Kementrian Kesehatan RI). Diabetes Melitus. 2020.

[3] Jing X, Chen J, Dong Y, Han D, Zhao H, Wang X, et al. Related factors of quality of life of type 2 diabetes patients: a systematic review and meta-analysis. Health Qual Life Outcomes 2018;16:1-14.

Https://doi.org/10.1186/s12955-018-1021-9.

[4] Iqbal Q, ul Haq N, Bashir S, Bashaar M. Profile and predictors of health related quality of life among type II diabetes mellitus patients in Quetta city, Pakistan. Health Qual Life Outcomes 2017;15:1-10.

Https://doi.org/10.1186/s12955-017-0717-6.

[5] Abedini MR, Bijari B, Miri Z, Shakhs Emampour $\mathrm{F}$, Abbasi A. The quality of life of the patients with diabetes type 2 using EQ-5D-5 L in Birjand. Health Qual Life Outcomes 2020;18:18. Https://doi.org/10.1186/s12955-020-1277-8.

[6] Azhar A, Gillani SW, Mohiuddin G, Majeed RA. A systematic review on clinical implication of continuous glucose monitoring in diabetes management. J Pharm Bioallied Sci 2020;12:102-11.

Https://doi.org/10.4103/jpbs.JPBS_7_20.

[7] Curtis SE, Boye KS, Lage MJ. Medication Adherence and Improved Outcomes 2017:20814.

[8] Schweyer L. Diabetes and quality of life. Rev Infirm 2015;64:45-6. Https://doi.org/10.1016/j.revinf.2015.02.017.

[9] Jannoo Z, Wah YB, Lazim AM, Hassali MA. Examining diabetes distress, medication adherence, diabetes self-care activities, diabetes-specific quality of life and healthrelated quality of life among type 2 diabetes mellitus patients. J Clin Transl Endocrinol 2017;9:48-54.

Https://doi.org/10.1016/j.jcte.2017.07.003.

[10] Zurita-Cruz JN, Manuel-Apolinar L, ArellanoFlores ML, Gutierrez-Gonzalez A, NajeraAhumada AG, Cisneros-González N. Health and 
quality of life outcomes impairment of quality of life in type 2 diabetes mellitus: A cross-sectional study. Health Qual Life Outcomes 2018;16:1-7. Https://doi.org/10.1186/s12955-018-0906-y.

[11] Rahman HF, Yulia, Sukarmini L. Efikasi diri, kepatuhan, dan kualitas hidup pasien diabetes melitus tipe 2 ( Self efficacy, adherence, and quality of life of patients with type 2 diabetes ). E-Jurnal Pustaka Kesehat 2017;5:108-13.

[12] Alfian SD, Sukandar H, Lestari K, Abdulah R. Medication Adherence Contributes to an Improved Quality of Life in Type 2 Diabetes Mellitus Patients: A Cross-Sectional Study. Diabetes Ther 2016;7:755-64. Https://doi.org/10.1007/s13300-016-0203-x.

[13] Perwitasari DA, Urbayatun S. Treatment Adherence and Quality of Life in Diabetes Mellitus Patients in Indonesia. SAGE Open 2016;6.

Https://doi.org/10.1177/2158244016643748.

[14] Saffari M, Lin CY, Chen H, Pakpour AH. The role of religious coping and social support on medication adherence and quality of life among the elderly with type 2 diabetes. Qual Life Res 2019;28:2183-93. Https://doi.org/10.1007/s11136-019-02183$\mathrm{z}$.

[15] Wichit N, Mnatzaganian G, Courtney M, Schulz $\mathrm{P}$, Johnson M. Randomized controlled trial of a family-oriented self-management program to improve self-efficacy, glycemic control and quality of life among Thai individuals with Type 2 diabetes. Diabetes Res Clin Pract 2017;123:37-48.

Https://doi.org/10.1016/j.diabres.2016.11.01 3.

[16] Alcubierre N, Martinez-Alonso M, Valls J, Rubinat E, Traveset $\mathrm{A}$, Hernández $\mathrm{M}$, et al. Relationship of the adherence to the Mediterranean diet with health-related quality of life and treatment satisfaction in patients with type 2 diabetes mellitus: A post-hoc analysis of a cross-sectional study. Health Qual Life Outcomes 2016;14:4-9. Https://doi.org/10.1186/s12955-016-0473-z.

[17] Chew BH. Medication adherence on quality of life among adults with type 2 diabetes mellitus: an exploratory analysis on the eddmqol study. Qual Life Res 2015;24:2723-31. Https://doi.org/10.1007/s11136-015-1006-7.

[18] Sharifirad G, Azadbakht L, Feizi A, Kargar M, Mohebi S. Review the key role of self-efficacy in diabetes care. J Educ Health Promot 2013;2:36. Https://doi.org/10.4103/2277-9531.115827.

[19] Morisky DE, Ang A, Krousel-Wood M, Ward HJ. 1. Morisky DE, Ang A, Krousel-Wood M, Ward HJ. Predictive Validity of a Medication
Adherence Measure for Hypertension Control. J Clin Hypertens 10. 2008; Predictive Validity of a Medication Adherence Measure for Hypertension Control. J Clin Hypertens 10 2008.

[20] Arslanian S, Bacha F, Grey M, Marcus MD, White $\mathrm{NH}$, Zeitler P. Evaluation and management of youth-onset type 2 diabetes: A position statement by the American diabetes association. Diabetes Care 2018;41:2648-68. Https://doi.org/10.2337/dci18-0052.

[21] Wermeling PR, Gorter KJ, van Stel HF, Rutten GEHM. Both cardiovascular and noncardiovascular comorbidity are related to health status in well-controlled type 2 diabetes patients: a cross-sectional analysis. Cardiovasc Diabetol

2012;11:1. Https://doi.org/10.1186/1475-2840-11-121.

[22] Farias MSJA de, Agra CL do M, Araújo LKA de, Correia DS, Cavalcante JC. Treatment adherence and life quality of diabetic patients assisted in the primary care division. Rev Soc Bras Clín Méd $2014 ; 12$.

[23] Nau DP. Recommendations for Improving Adherence to Type 2 Diabetes Mellitus Therapy-Focus on Optimizing Oral and NonInsulin Therapies. Am J Manag Care 2012;VOL. 18, N:49-54.

[24] Bailey C, Kodack M. Patient adherence to medication requirements for therapy of type 2 diabetes. Int J Clin Pract Wiley, 2011;65 (3):pp.314.

[25] Kim CJ, Schlenk EA, Kim DJ, Kim M, Erlen JA, Kim SE. The role of social support on the relationship of depressive symptoms to medication adherence and self-care activities in adults with type 2 diabetes. J Adv Nurs 2015;71:2164-75.

Https://doi.org/10.1111/jan.12682.

[26] Gu L, Wu S, Zhao S, Zhou H, Zhang S, Gao M, et al. Association of social support and medication adherence in Chinese patients with type 2 diabetes mellitus. Int J Environ Res Public Health 2017;14:1-10. Https://doi.org/10.3390/ijerph14121522.

[27] Alfian SD, Sukandar H, Arisanti N, Abdulah R. Complementary and Alternative Medicine Use Decreases Adherence to Prescribed Medication in Diabetes Patients. J Acupunct Meridian Stud 2018;11:337.

Https://doi.org/10.1016/j.jams.2018.10.002.

[28] Shi M, Xu MY, Liu ZL, Duan XY, Zhu YB, Shi HM, et al. Effectiveness of family involvement in newly diagnosed type 2 diabetes patients: A follow-up study. Patient Educ Couns 2016;99:776-82.

Https://doi.org/10.1016/j.pec.2015.12.018.

Yuli Wahyuni / Improving The Quality of Life of Patients with Diabetes Mellitus Type 2 with Treatment Adherence 
[29] Zaragoza-Marti A, Ferrer-Cascales R, HurtadoSanchez J., Laguna-Perez A, Cabanero-Martinez M. Relationship Between Adherence To The Mediterranean Diet And Health-Related Quality Of Life And Life Satisfaction Among Older Adults. Nutr Heal Aging 2018;22. 